ISSN1027-5495. Functional Materials, 24, No.3 (2017), p. 481-489

doi:https://doi.org/10.15407/fm24.03.481

(C) 2017 - STC “Institute for Single Crystals"

\title{
Preparation and characterization of mortar mixes containing organic acid/expanded vermiculite composite PCM
}

\author{
Xinzhong Zhang ${ }^{1}$, Weizhun Jin ${ }^{1}$, Yajun Lv $^{2}$, Haibin Zhang ${ }^{3}$, \\ Weibing Zhou ${ }^{4}$ Fangyi Ding ${ }^{2}$
}

${ }^{1}$ School of Civil Engineering and Communication, North China University of Water Resources and Electric Power, Henan, Zhengzhou, 450045, China ${ }^{2}$ School of Architecture, North China University of Water Resources and

Electric Power, Henan, Zhengzhou 450045, China

${ }^{3}$ Faculty of Architecture and Urban Planning, Chongqing University, Chongqing, 400030, China

${ }^{4}$ School of Materials Science and Engineering, Wuhan University of Technology, Hubei, Wuhan, 430070, China

\section{Received February 1, 2017}

In this paper, capric acid (CA) and palmitic acid (PA) binary PCM/expanded vermiculite (CAPA/EVM) form stable composite PCM (FS-CPCM) was firstly synthesized by adsorption method. The EVM had the optimal adsorption rate when the mass ratio of CA-PA to EVM was 45:55. The FT-IR results indicated that there was no chemical reaction between binary PCM and EVM. After the thermal cycles for 50 times, the mass loss of the prepared CA-PA/EVM FS-CPCM was $2.8 \%$. However, the latent heat was reduced by $16.10 \%$. Furthermore, thermal energy storage (TES) mortar mixes were prepared by replacing sand aggregates with the fabricated CA-PA/ EVM FS-CPCM. The effect of replacing sand aggregates with CA-PA/EVM FS-CPCM on compressive and flexural strength of the mortar mixes was investigated by mechanical experiments. The prepared mortar mixes with CA-PA/EVM FS-CPCMs aggregate exhibited good thermal performance and could be preferentially potential PCM for thermal regulation and energy saving in buildings.

Keywords: Capric acid, palmitic acid, expanded vermiculite, thermal energy storage, mortar mixes.

В данной работе методом адсорбции был впервые синтезирован двойной $\mathrm{PCM} /$ расширенный вермикулит (CA-PA / EVM) с использованием комбинированной PCM (FS-CPCM), каприновой кислоты (СA) и пальмитиновой кислоты (PA). У EVM была оптимальная скорость адсорбции, когда отношение масс CA-PA к EVM составляло 45:55. Результаты FT-IR показали, что между бинарным PCM и EVM не было химической реакции. После 50 термических циклов потери массы подготовленного CA-ПА / EVM FS-CPCM составляли 2,8\%. Однако скрытая теплота уменьшилась на 16,10\%. Кроме того, материалы для сохранения тепловой энергии (TES) были получены путем замены песчаных заполнителей на изготовленную CA-PA / EVM FS-CPCM. Механические эксперименты исследовали влияние замещения песчаных заполнителей на CA-ПА / EVM FS-CPCM на прочность на сжатие и изгиб растворных смесей. Готовые растворные смеси с агрегатом CA-PA / EVM FS-CPCM демонстрировали хорошие тепловые характеристики и могли быть предпочтительными потенциальными РСМ для термического регулирования и экономии энергии в зданиях. 
Підготовка та характеристика розчинних сумішей для вермикуліту, що містять суміш органічна кислота / вспученная композиція РCM. Xinzhong Zhang, Weizhun Jin, Yajun Lv, Haibin Zhang, Weibing Zhou, Fangyi Ding

\begin{abstract}
У даній роботі методом адсорбщії був вперше синтезований подвійний $\mathrm{PCM}$ / розширений вермикуліт (CA-PA / EVM) 3 використанням комбінованої PCM (FS-CPCM), капринової кислоти (СА) і пальмітинової кислоти (РА). У EVM була оптимальна швидкість адсорбції, коли відношення мас CA-PA до EVM становило 45:55. Результати FT-IR показали, що між бінарним PCM і EVM не було хімічної реакції. Після 50 термічних циклів втрати маси підготовленого CA-ПА / EVM FS-CPCM становили 2,8\%. Однак прихована теплота зменшилася на 16,10\%. Крім того, матеріали для збереження теплової енергії (TES) були отримані шляхом заміни піщаних заповнювачів на виготовлену CA-PA / EVM FS-CPCM. Механічні експерименти досліджували вплив заміщення піщаних заповнювачів на CA-ПА / EVM FS-CPCM на міцність на стиск і вигин розчинних сумішей. Готові розчинні суміші з агрегатом CA-PA / EVM FSCPCM демонстрували хороші теплові характеристики і могли бути кращими потенщійними РСМ для термічного регулювання і економії енергії в будівлях.
\end{abstract}

\section{Introduction}

Over the past decades, energy consumption in buildings has increased steadily because of the growth of population and the improvement of human comfort standards [1]. Various activities in buildings, such as heating, cooling, and air conditioning, account for nearly $40 \%$ of the global energy consumption $[2,3]$. Therefore, the efficient use of energy in buildings has attracted increasing attention so as to solve the problems of energy consumption and environmental pollution.

Thermal energy storage (TES) has been always regarded as one of the potential techniques to enhance energy efficiency in buildings. Latent heat energy storage by organic acid PCMs is recognized as the most attractive among these TES techniques by virtue of the storage and release of high density energy at small temperature variations, which can maintain the indoor environment at the comfortable temperature for human body [4].

In recent years, various investigations have been implemented to study the application of PCMs in buildings to minimize the building energy consumption [5]. Due to the proper thermal storage characteristics and chemical compatibility with building materials, many organic PCMs such as fatty acids, paraffin, high alcohols and their mixture have been considered as the preferred latent heat materials for thermal energy storage in buildings [6].

The organic PCMs is generally added into the latent heat materials in building components such as concrete, gypsum board, mortar and other building envelopes [7]. However, the organic PCMs has the disadvantages of liquid migration and leakage in the phase change process. Therefore, the addition of PCMs into supporting materials to form stable composite PCMs has been fabricated to avoid the abovementioned problem [8]. Up to now, various materials have been selected as the supporting ma- trix, such as gypsum $[9,10]$, expanded vermiculite [11-13], expanded graphite [14-16], perlite [17-19], expanded fly ash [20], and montmorillonite $[21,22]$.

Vermiculite is a kind of phyllosilicate mineral, the volume of which can expand to 8 to 30 times of its original size [23]. Because of the expanded microstructures, the expanded vermiculite is characterized by light weight, low thermal conductivity and high porosity. In addition, this material possesses a multilayer structure and is much cheaper compared with some other porous supporting materials. Therefore, the expanded vermiculite is considerably appropriate for the supporting matrix to fabricate form stable composite PCMs in buildings.

This paper aims to study the CA-PA binary PCM/expanded vermiculite(CA-PA/EVM) form stable composite PCM(FS-CPCM) for thermal energy utilization in buildings. In this paper, CA-PA binary material was selected as the PCM because of the proper temperature range (around $26{ }^{\circ} \mathrm{C}$ ), and expanded vermiculite was utilized as the supporting matrix. Moreover, CA-PA/EVM FSCPCM was synthesized by adsorption method. The thermal property and thermal stability of the FS-CPCM before and after thermal cycles were analyzed by DSC, FT-IR, and mass losses, respectively. In addition, the thermal storage mortar was prepared by replacing medium sand aggregate with the prepared CA-PA/EVM FS-CPCM. Finally, the mechanical and thermal energy storage(TES) properties of the mortar containing FS-CPCMs fabricated with different volume fractions were characterized.

\section{Preparation of the composite PCM}

\subsection{Materials}

Capric acid ( $\left.\mathrm{CA}, \mathrm{CH}_{3}\left(\mathrm{CH}_{2}\right)_{8} \mathrm{COOH}, \mathrm{AR}\right)$ and Palmitic acid (PA, $\left.\mathrm{CH}_{3}\left(\mathrm{CH}_{2}\right)_{14} \mathrm{COOH}, \mathrm{AR}\right)$ were purchased from Jiehui Chemical Co., Ltd., China. Expanded vermiculite was purchased from 
Jinli mining industry co., Ltd. Table 1 shows the chemical composition of the EVM. It can be seen that the EVM is mainly composed of $\mathrm{SiO}_{2}$, $\mathrm{Al}_{2} \mathrm{O}_{3}, \mathrm{MgO}$ and $\mathrm{Fe}_{2} \mathrm{O}_{3}$.

\subsection{Preparation of CA-PA/EVM FS- CPCM}

Firstly, the CA-PA eutectic mixture was prepared. According to the CA-PA binary phase diagram measured by cooling curve method as shown in Fig.1, the mass ratios of CA and PA in the eutectic mixture were determined as 75wt.\% and 25wt.\%, respectively. Secondly, the CA-PA/ EVM FS-CPCM was fabricated by adsorption method. EVM can hardly adsorb a large quantity of melting PCM by simple immersion. This is because that the interlayer space of EVM was blocked up with the impurity, which prevented the melting PCM from entering the layer space. To remove the impurity in the interlayer of the EVM, 10\% hydrochloric acid solution was utilized to immerse raw EVM for $4 \mathrm{~h}$, and then the immersed EVM was cleaned by water. The EVM treated by acid solution was placed and dried in the oven at $110{ }^{\circ} \mathrm{C}$. The morphology of EVM before and after the treatment by hydrochloric acid was observed by a SEM instrument (SEM, JSM-IT3000).

As the adsorption ability of the expanded vermiculite is limited, the expanded vermiculite will no longer adsorb CA-PA binary PCM at the maximum adsorption rate, and the composite PCM will not leak during phase change process. Thus, in order to determine the optimal adsorption rate of expanded vermiculite, a series of composites with different mass ratios of CA-PA to $\operatorname{EVM}(45: 55$, 50:50, 55:45, 60:40, 65:35) were prepared and conducted with the thermal stability test. During this test, the optimal adsorption rate of expanded vermiculite can be determined by measuring the mass losses of the composite PCM one hour before and after the heating treatment.

DSC, FT-IR and mass losses were tested before and after 50 thermal cycles in order to investigate the thermal reliability and chemical stability of CA-PA/EVM FS-CPCM. Thermal properties of the composite PCM were measured by differential scanning calorimetry (DSC,Pyris-1), and the operation temperature ranged from $0^{\circ} \mathrm{C}$ to $70^{\circ} \mathrm{C}$, with the ramping rate of $5^{\circ} \mathrm{C} / \mathrm{min}$ under nitrogen gas atmosphere. The chemical compatibility between CA-PA binary PCM and EVM was investigated by FT-IR spectroscopy technique. FT-IR spectra were carried out in the frequency range of 4000-400 $\mathrm{cm}^{-1}$ (FT-IR, BioRad FTS 6000).
Table 1. Chemical composition of expanded vermiculite.

$(1-1)$

\begin{tabular}{|c|c|c|c|c|c|}
\hline $\begin{array}{c}\text { Consti- } \\
\text { tute }\end{array}$ & $\mathrm{SiO}_{2}$ & $\mathrm{Al}_{2} \mathrm{O}_{3}$ & $\mathrm{Fe}_{2} \mathrm{O}_{3}$ & $\mathrm{MgO}$ & $\mathrm{TiO}_{2}$ \\
\hline Ratio(\%) & 42.35 & 14.69 & 23.53 & 11.59 & 0.81 \\
\hline
\end{tabular}

$(1-2)$

\begin{tabular}{|c|c|c|c|c|}
\hline $\begin{array}{c}\text { Consti- } \\
\text { tute }\end{array}$ & $\mathrm{K}_{2} \mathrm{O}$ & $\mathrm{Na}_{2} \mathrm{O}$ & $\mathrm{MnO}$ & Else \\
\hline Ratio(\%) & 5.96 & 1.58 & 0.045 & 0.445 \\
\hline
\end{tabular}

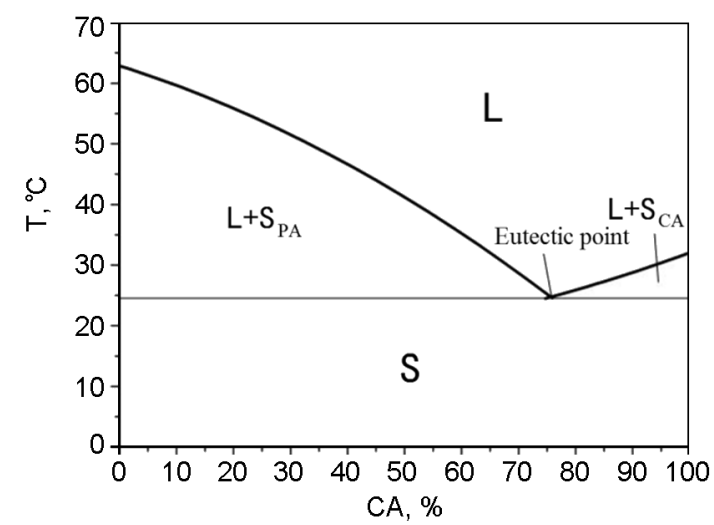

Fig.1. CA-PA binary phase diagram.

\subsection{Mix proportions of mortar mixes with CA-PA/EVM FS-CPCMs and test methods}

Mortar mixes containing PCM composite can be utilized as the thermal energy storage(TES) materials to realize building energy efficiency. In this study, TES mortar mixes containing CA-PA/ EVM FS-CPCMs were prepared with the fixed water to cement of 0.63 . The medium sand aggregates were replaced by CA-PA/EVM composites with different volume fractions ranging from $0 \%$, $20 \%, 30 \%$, and $40 \%$ to $50 \%$. The components of TES mortar mixes are as shown in Table 2.

Fresh mortar mixes were cast in steel moulds with the dimension of $40 \times 40 \times 160 \mathrm{~mm}^{3}$. The mixes were compacted by a shaker. All the specimens were kept in molds for $24 \mathrm{~h}$ at room temperature, and then the specimens were demoulded and placed in standard curing room for 28 days. Moreover, flexural strength of the specimens was measured by three-point bending test, in which the load rate was $50 \mathrm{~N} / \mathrm{s}$ and the supporting span was $100 \mathrm{~mm}$. The compressive strength of the specimens was examined under the specimen contact area of $40 \times 40 \mathrm{~mm}^{2}$ and the load rate of $2.4 \mathrm{kN} / \mathrm{s}$. In the compressive and flexural strength experiments, the average measured value and standard deviation were obtained by three specimens as a group. 
Table 2. The formula of mortar mixes with FS-CPCMs.

\begin{tabular}{|c|c|c|c|c|c|}
\hline $\begin{array}{c}\text { Sam- } \\
\text { ples }\end{array}$ & $\begin{array}{c}\text { Volume } \\
\text { fraction }\end{array}$ & $\begin{array}{c}\text { Cement } \\
(\mathrm{g})\end{array}$ & $\begin{array}{c}\text { Sand } \\
(\mathrm{g})\end{array}$ & $\begin{array}{c}\text { CA-PA/EVM } \\
\text { composite(g) }\end{array}$ & W/C \\
\hline $1 \#$ & $20 \%$ & 450 & 1080 & 100 & 0.63 \\
\hline $2 \#$ & $30 \%$ & 450 & 945 & 150 & 0.63 \\
\hline $3 \#$ & $40 \%$ & 450 & 810 & 200 & 0.63 \\
\hline $4 \#$ & $50 \%$ & 450 & 675 & 250 & 0.63 \\
\hline
\end{tabular}

2.4 Thermal performance tests of mortar mixes with CA-PA/EVM FS-CPCMs

To evaluate the thermal performance of mortar mixes with CA-PA/EVM FS-CPCMs, the test boxes were designed as shown in Fig. 2. Three boxes were constructed by using mortar mixes with $0 \%, 20 \%$ and $30 \%$ replacement of CA-PA/EVM composite aggregate. Temperature variations in inner space of test boxes were measured by the $\mathrm{T}$ type thermocouples(with an accuracy of $0.2^{\circ} \mathrm{C}$ ) placed in the inner space (Fig. 2 b). The temperature values were recorded via a data logger with the interval of 30 s in the heating and cooling periods. Three test boxes were heated via a heating chamber where the temperature was kept at $45^{\circ} \mathrm{C}$. When the inner air temperature of the test boxes was $45^{\circ} \mathrm{C}$, the heating process was stopped and the boxes were spontaneously placed in the allowed place to cool to $16^{\circ} \mathrm{C}$.

\section{Result and discussion}

\subsection{Microstructure of the EVM}

Fig. 3 illustrates the morphology of EVM before and after the treatment by acid solution. It can be seen from Fig. 3a that EVM showed typical layer structure, but the layer structure of EVM was blocked up with impurities which prevents liquid PCM from entering the
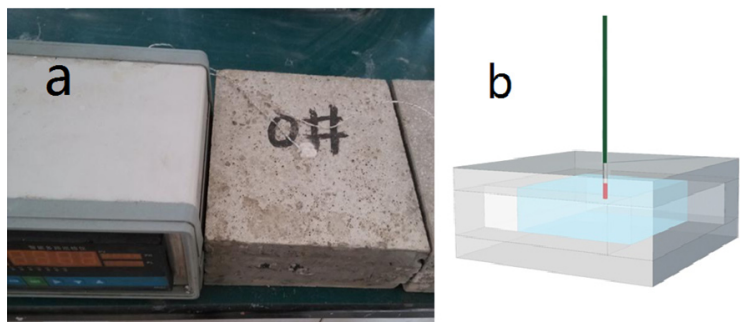

Fig. 2 Test system of thermal performance with PCM composite:(a) photograph of test system; (b) position of the thermocouple.

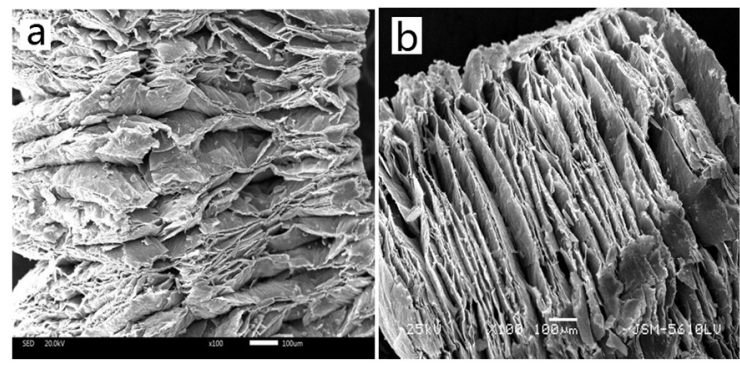

Fig. 3. SEM morphology of EVM before and after being treated by hydrochloric acid:(a) Microstructure of raw EVM; (b) Microstructure of EVM treated by hydrochloric acid.

layer space. In the morphology of EVM after being treated by hydrochloric acid as shown in Fig. $3 \mathrm{~b}$ the impurities were removed and the layer space of EVM was larger and cleaner than the EVM microstructure before the treatment by acid solution. Therefore, the specimen treated by acid solution is the preferentially potential supporting matrix which can enhance the adsorption rate of EVM to melted PCM.

\subsection{Thermal stability of CA-PA binary PCM}

The binary CA-PA mixture PCM was firstly prepared by mixture method, and the mass fractions of CA and PA were $75 \%$ and $25 \%$, respectively.

Thermal properties such as phase change temperature and enthalpy are key parameters

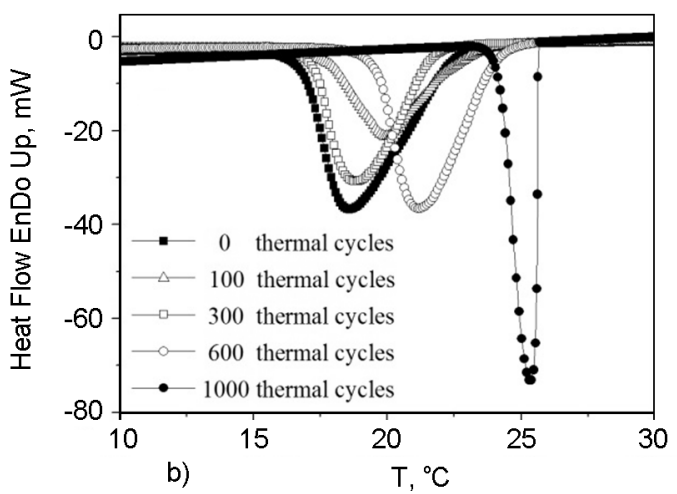

Fig. 4 The DSC curves of CA-PA binary PCM before and after thermal cycling:(a) the melting process; (b) the freezing process. 
Table 3. Thermal properties of the fabricated CA-PA binary PCM.

\begin{tabular}{|c|c|c|c|c|}
\hline \multirow{2}{*}{$\begin{array}{c}\text { Speci- } \\
\text { men } \\
\text { Cycle } \\
\text { index }\end{array}$} & \multicolumn{2}{|c|}{ Charging process } & \multicolumn{2}{|c|}{ Discharging process } \\
\hline & $\begin{array}{l}\text { Delta } \\
\mathrm{H}, \mathrm{J} / \mathrm{g}\end{array}$ & $\begin{array}{l}\text { Melting } \\
\text { tempera- } \\
\text { ture, }{ }^{\circ} \mathrm{C}\end{array}$ & $\begin{array}{l}\text { Delta } \\
\mathrm{H}, \mathrm{J} / \mathrm{g}\end{array}$ & $\begin{array}{l}\text { Freezing } \\
\text { tempera- } \\
\text { ture, }{ }^{\circ} \mathrm{C}\end{array}$ \\
\hline 0 & 132.71 & 26.38 & -130.38 & 22.58 \\
\hline 100 & 162.96 & 26.11 & -151.02 & 22.57 \\
\hline 300 & 166.99 & 26.60 & -154.48 & 21.72 \\
\hline 600 & 172.12 & 29.62 & -167.15 & 24.15 \\
\hline 1000 & 154.35 & 33.15 & -159.22 & 25.65 \\
\hline
\end{tabular}

affecting the application of thermal regulation of PCM in buildings. In this paper, an accelerated thermal cycling experiment was conducted to examine thermal properties and thermal stabilities of CA-PA binary mixture PCM. The DSC curves of CA-PA binary PCM subject to thermal cycling are presented in Fig. 4 and Table 3.

It can be seen that after 1000 thermal cycling, the melting temperature of CA-PA binary $\mathrm{PCM}$ increased from $26.38^{\circ} \mathrm{C}$ to $33.15^{\circ} \mathrm{C}$, the freezing temperature changed from $22.58^{\circ} \mathrm{C}$ to $25.65^{\circ} \mathrm{C}$, increasing by $6.77^{\circ} \mathrm{C}$ and $3.07^{\circ} \mathrm{C}$, respectively. The latent heat changed from $132.71 \mathrm{~J} / \mathrm{g}$ to $154.35 \mathrm{~J} / \mathrm{g}$ in the melting process and $130.38 \mathrm{~J} / \mathrm{g}$ to $159.22 \mathrm{~J} / \mathrm{g}$ in the freezing process, increasing by $16.30 \%$ and $22.11 \%$, respectively.

The results indicate that both phase change temperature and latent heat after the accelerated thermal cycling have increased compared with that before the thermal cycling. The melting temperature was between $26.38^{\circ} \mathrm{C}$ and $33.15^{\circ} \mathrm{C}$, and the freezing temperature was between $22.58^{\circ} \mathrm{C}$ and $25.65^{\circ} \mathrm{C}$, which were all in range of human comfort temperature. The increase of latent heat is conductive to building TES application. Therefore, CA-PA binary PCM possesses good thermal stability and is the preferentially potential PCM for building energy regulation.

\subsection{The optimal adsorption rate of EVM to CA-PA PCM}

Table 4 presents mass loss percentage of the CA-PA/EVM with different mass ratios. As can be seen from Table 4, with the increase of mass percentage of CA-PA in composite PCM, the mass loss percentage of the composite PCM after heat treatment increased accordingly. When the mass ratio of CA-PA to EVM was 45:55, the mass loss percentage of CA-PA/EVM
Table 4. The mass loss percentage of CA-PA/ EVM composite PCM with different mass ratios after heat treatment.

\begin{tabular}{|c|c|c|c|c|c|}
\hline $\begin{array}{c}\text { Mass ratio, } \\
\text { CA-PA/ } \\
\text { EVM }\end{array}$ & $45 / 55$ & $50 / 50$ & $55 / 45$ & $60 / 40$ & $65 / 35$ \\
\hline $\begin{array}{c}\text { Before heat } \\
\text { treatment }\end{array}$ & 5.04 & 5.03 & 5.096 & 5.074 & 5.04 \\
\hline $\begin{array}{c}\text { After heat } \\
\text { treatment }\end{array}$ & 4.9940 & 4.9558 & 4.8687 & 4.6409 & 4.4034 \\
\hline $\begin{array}{c}\text { Mass loss } \\
\text { percentage }\end{array}$ & $0.91 \%$ & $1.48 \%$ & $4.46 \%$ & $8.54 \%$ & $12.63 \%$ \\
\hline
\end{tabular}

composite PCM was $0.91 \%$, which was the minimum. However, when the mass ratio of CA-PA to EVM was 65:35, the mass loss percentage of CA-PA/EVM composite PCM was $12.63 \%$, which was the maximum. Hence, when the mass ratio of CA-PA to EVM was 45:55, the mass loss was minimum, and the EVM had the optimal adsorption rate. Therefore, the following CAPA/EVM composite PCM utilized in this paper were prepared with the mass ratio of 45:55.

\subsection{Chemical properties of CA-PA/EVM FS-CPCM}

Chemical compatibility between the binary mixture PCM and EVM was investigated by FT-IR spectroscopy analysis method. Fig. 5 illustrates the FT-IR spectrums of EVM, the CAPA binary PCM, CA-PA/EVM and CA-PA/EVM after 50 thermal cycling.

As can be seen from the spectrum of EVM in Fig. 5, the peaks at $3421 \mathrm{~cm}^{-1}$ and $1639 \mathrm{~cm}^{-1}$ were assigned respectively to $\mathrm{OH}$ stretching and bending vibration of the interlayer water. The characteristic peaks of Si-O stretching vibration and $\mathrm{Si}-\mathrm{O}-\mathrm{Si}$ bending vibration were at $1008 \mathrm{~cm}^{-1}$ and $441 \mathrm{~cm}^{-1}$, respectively. In the spectrum of CA-PA, the absorption peaks caused by the in-plane bending vibration and out-of-plane bending vibration of functional group $-\mathrm{OH}$ were at $1432 \mathrm{~cm}^{-1}$ and $936 \mathrm{~cm}^{-1}$. The peaks at $2919 \mathrm{~cm}^{-1}$ and $2850 \mathrm{~cm}^{-1}$ represents the asymmetrical vibration and symmetrical vibration of functional group of $-\mathrm{CH}_{3}$ and $-\mathrm{CH}_{2}$. Compared with the FT-IR spectra of CA-PA and EVM, it can be clearly found that the FT-IR spectrum of CA-PA/EVM contains the characteristic peaks of CA-PA and EVM. The infrared spectrum of CA-PA/EVM has no significantly new peaks, but just partial peaks have small deviation. Thus, the results of FT-IR analysis indicate that there was no chemical interaction between the CA-PA and EVM, and the interactions between the components of the composites were physical in nature. 


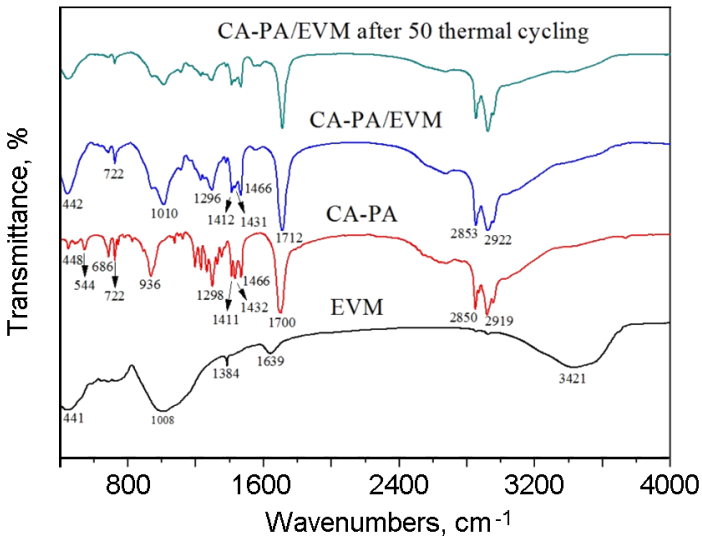

Fig. 5 FT-IR spectra of EVM, CA-PA, CA$\mathrm{PA} / \mathrm{EVM}$ and CA-PA/EVM after 50 thermal cycling.

Fig. 5 indicates that the characteristic peak forms and positions were almost unchanged in the spectrum of CA-PA/EVM after 50 thermal cycling compared with the spectrum of CA-PA/EVM before thermal cycling. The results indicate that the chemical structure of the FS-CPCM remained stable in the process of thermal cycling. Therefore, the prepared CA-PA/EVM FS-CPCMs have good chemical compatibility.

\subsection{Thermal stability of CA-PA/EVM FS-CPCM}

Thermal stability is a key property for FSCPCM applied in buildings for thermal energy storage. In this study, $10 \mathrm{~g}$ fabricated CA-PA/ EVM composite and thermal cycling test with the temperature ranged from $0^{\circ} \mathrm{C}$ to $40^{\circ} \mathrm{C}$, were employed to evaluate the thermal stability with respect to mass losses. As can be seen from Fig. 6 , with the increase of the thermal cycling from $10,20,30,40$ to 50 , the mass losses of the composite PCM were $0.17 \mathrm{~g}, 0.2 \mathrm{~g}, 0.25 \mathrm{~g}, 0.28 \mathrm{~g}$ and

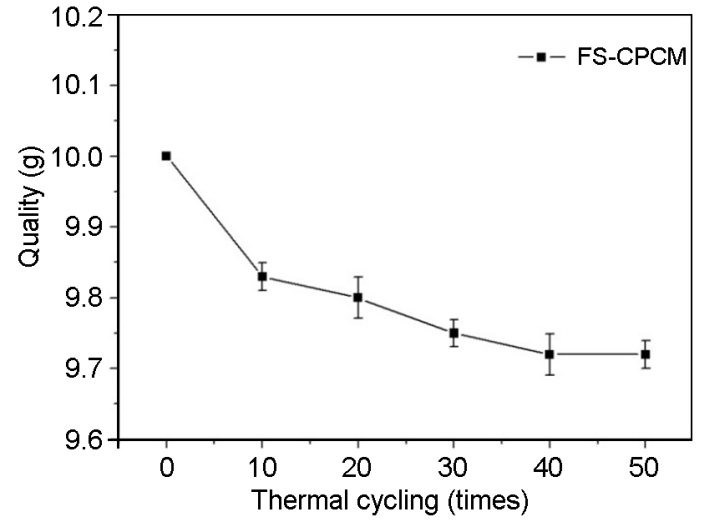

Fig. 6 The mass losses of the composite PCM subject to thermal cycling.

Table 5. Thermal properties of the fabricated CA-PA/EVM FS-CPCM.

\begin{tabular}{|c|c|c|c|c|}
\hline \multirow{2}{*}{$\begin{array}{c}\text { Speci- } \\
\text { men }\end{array}$} & \multicolumn{2}{|c|}{ Charging process } & \multicolumn{2}{c|}{$\begin{array}{c}\text { Discharging pro- } \\
\text { cess }\end{array}$} \\
\cline { 2 - 5 } $\begin{array}{c}\text { Cycle } \\
\text { index }\end{array}$ & $\begin{array}{c}\text { Delta H, } \\
\mathrm{J} / \mathrm{g}\end{array}$ & $\begin{array}{c}\text { Melting } \\
\text { tempera- } \\
\text { ture }\end{array}$ & $\begin{array}{c}\text { Delta } \\
\mathrm{H}, \mathrm{J} / \mathrm{g}\end{array}$ & $\begin{array}{c}\text { Freezing } \\
\text { tempera- } \\
\text { ture, }{ }^{\circ} \mathrm{C}\end{array}$ \\
\hline 0 & 94.45 & 23.40 & -95.76 & 22.80 \\
\hline 50 & 93.51 & 25.59 & -80.34 & 23.50 \\
\hline
\end{tabular}

$0.28 \mathrm{~g}$, accounting for $1.7 \%, 2.0 \%, 2.5 \%, 2.8 \%$ and $2.8 \%$ of the total composite PCMs. Based on the results of thermal cycling tests, it can be concluded that the CA-PA/EVM composite exhibits good thermal stability in their operating temperature range and it is a preferred PCM for TES application in buildings.

The thermal properties of the fabricated CAPA/EVM FS-CPCM and CA-PA/EVM FS-CPCM subject to 50 thermal cycling were examined by DSC analysis. The DSC curves are presented in Fig. 7 and Table 5 . It can be seen that the melting and freezing temperatures were $23.40^{\circ} \mathrm{C}$
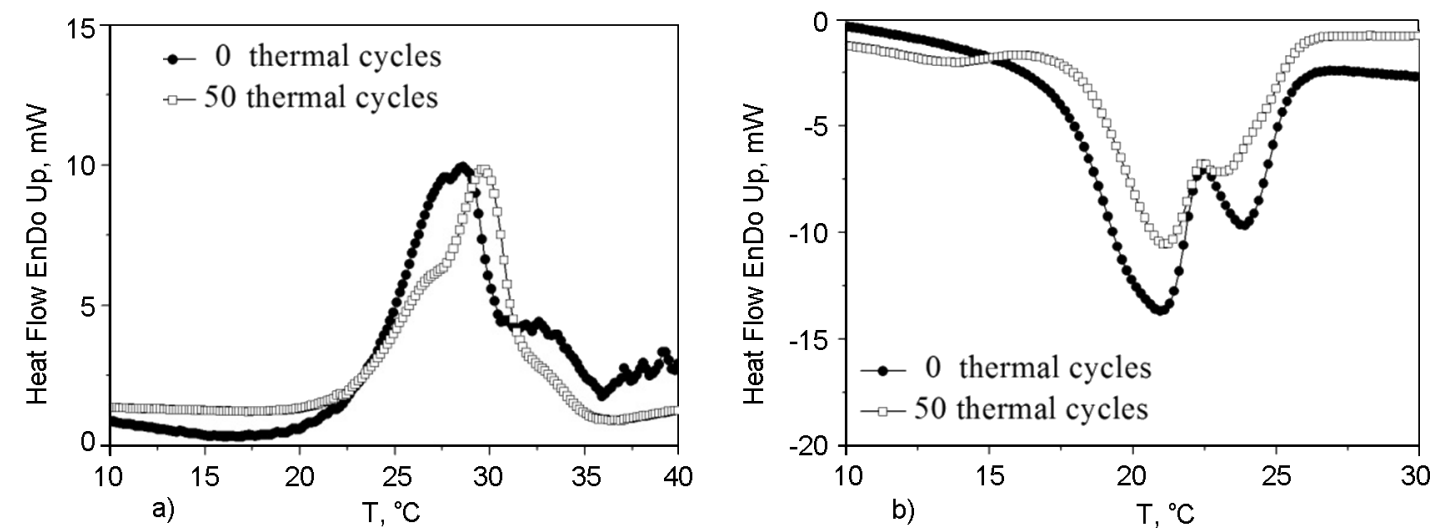

Fig. 7. The DSC curves of CA-PA/EVM FS-CPCM before and after thermal cycling:(a) the melting process; (b) the freezing process. 

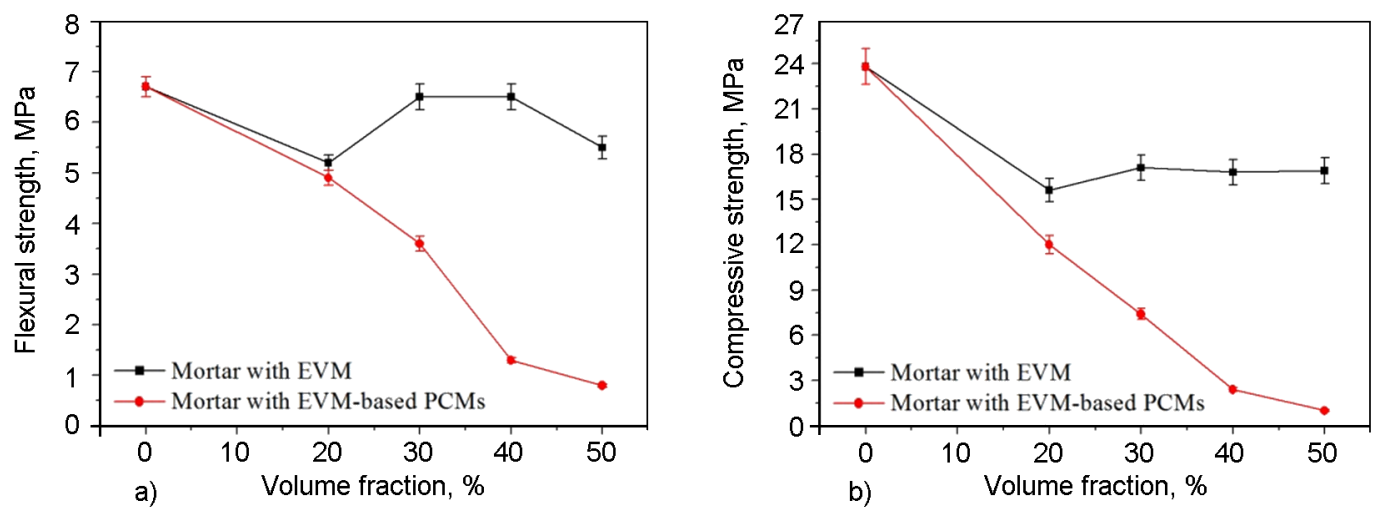

Fig. 8. Flexural and compressive strength of mortar mixes with different volume fraction of EVM and CAPA/EVM composite:(a) flexural strength; (b) compressive strength.

and $22.80^{\circ} \mathrm{C}$ for EVM-based FS-CPCM, and $25.59^{\circ} \mathrm{C}$ and $23.50^{\circ} \mathrm{C}$ for EVM-based FS-CPCM after 50 thermal cycles. After 50 thermal cycling, the melting and freezing temperatures were increased by $2.19^{\circ} \mathrm{C}$ and $0.7^{\circ} \mathrm{C}$, respectively. However, the phase change temperatures were all in the range of $22^{\circ} \mathrm{C} \sim 26^{\circ} \mathrm{C}$, which is the human thermal comfort temperature.

Latent heat of melting and freezing was $94.45 \mathrm{~J} / \mathrm{g}$ and $95.76 \mathrm{~J} / \mathrm{g}$ for the original CA-PA/ EVM FS-CPCM, $93.51 \mathrm{~J} / \mathrm{g}$ and $80.34 \mathrm{~J} / \mathrm{g}$ for the composite after 50 thermal cycling. Compared with the original CA-PA/EVM, the latent heat after 50 thermal cycling changed by $-2.05 \%$ in the melting process and $-16.10 \%$ in the freezing process. The results indicate that the variation of latent heat in the melting process was small and acceptable for TES application. However, the latent heat significantly changed in freezing process, and it is necessary to carry out further study to enhance the thermal stability.

\subsection{Mechanical properties of mortar mixes with CA-PA/EVM FS-CPCMs}

The mechanical property of TES mortar mixes with the aggregate replacement of CA-PA/ EVM FS-CPCM was an important parameter for the application in buildings. In this section, EVM and CA-PA/EVM composite with different volume fractions ranged from $20 \%, 30 \%$, and $40 \%$ to $50 \%$ were employed as a replacement of sand aggregate in the mortar mixes, and the compressive strength and flexural strength were studied by experiments to investigate the mechanical properties of the prepared mixes. The formula of the TES mortars are presented in Table 2 and the results of flexural and compressive strength are presented in Fig. 8

Fig. 8a and Fig. 8b present the flexural strength and compressive strength results of mortar mixes with only EVM and CA-PA/ EVM FS-CPCMs aggregate replacement after 28-days curing, respectively. Overall, the flexural strength and compressive strength of mortar mixes decreased with the increase of aggregate replacement by volume. As can be seen from Fig. 8, the flexural strength and compressive strength of TES mortar mixes containing CA-PA/EVM FS-CPCMs aggregate decreased with the increase of aggregate replacement. However, flexural strength and compressive strength of mortar mixes slightly decreased with only EVM aggregate replacement and tended to level off.

The flexural strength of mortar mixes after the 28-day curing approximately decreased by $23.4 \%, 3.0 \%, 3.0 \%$ and $17.9 \%$ for $20 \%$, $30 \%, 40 \%$ and $50 \%$ only EVM aggregate replacement by volume. The reduction of flexural strength was approximately $26.9 \%, 46.3 \%$, $80.6 \%$ and $88.1 \%$ for $20 \%, 30 \%, 40 \%$ and $50 \%$ CA-PA/EVM FS-CPCMs replacement by volume. The compressive strength of mortar after 28-day curing approximately reduced by $34.5 \%, 28.2 \%, 29.4 \%$ and $28.9 \%$ for $20 \%$, $30 \%, 40 \%$ and $50 \%$ only EVM replacement by volume, and the compressive strength reduction decreased by approximately $49.6 \%, 68.9 \%$, $89.9 \%$ and $95.8 \%$ for $20 \%, 30 \%, 40 \%$ and $50 \%$ CA-PA/EVM FS-CPCMs replacement by volume, respectively.

The slight reduction in mechanical properties of mortar mixes containing only EVM aggregate replacement is caused by the layer structure, in which the cement condenses and the mortar mixes possess high strength. However, in the mortar mixes with CA-PA/EVM FS-CPCMs aggregate replacement, the layer space of EVM was filled with solidification CA-PA PCMs with lower mechanical properties, which caused the reduction in compressive and flexural strength, especially when the aggregate replacement of volume fraction was greater than $30 \%$. 

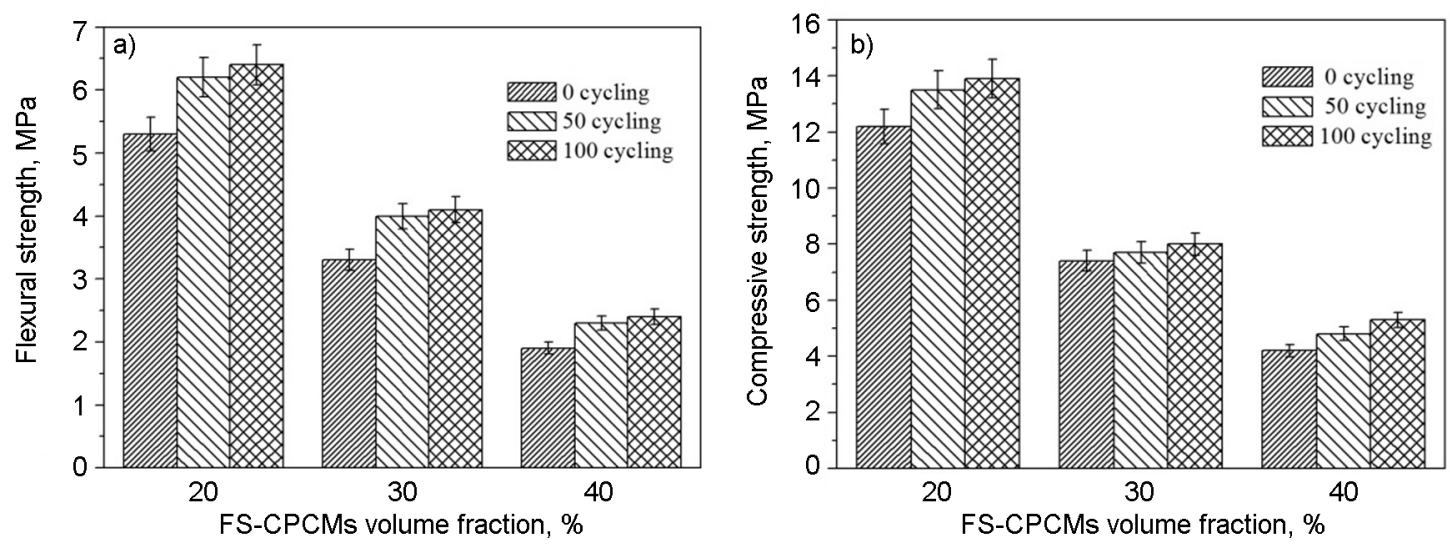

Fig. 9. Flexural and compressive strength of mortar mixes after thermal cycling:(a) flexural strength; (b) compressive strength.

\subsection{Impact of thermal cycling on me- chanical stability of mortar mixes with CA-PA/EVM FS-CPCMs}

Environmental temperature fluctuation around the phase change temperature will result in solid-liquid conversion of PCMs, which can reduce the mechanical strength of mortar mixes. In this study, in order to investigate the effect of temperature variation on mechanical stability of the TES mortar mixes, experiments were carried out to examine the flexural and compressive strength of mortar mixes with CA-PA/EVM FS-CPCMs before and after the thermal cycling. The flexural and compressive strength of mortar mixes with CA-PA/EVM FSCPCMs subject to 0, 50 and 100 thermal cycling is presented in Fig. 9a and Fig. 9b.

Overall, with the increase of thermal cycling from 0 and 50 to 100 times, the flexural and compressive strength of mortar mixes was enhanced accordingly. In flexural strength experiments, by taking $20 \% \mathrm{CA}-\mathrm{PA} / \mathrm{EVM}$ aggregate replacement by volume as an example, the flexural strength is $5.3 \mathrm{MPa}$ for 0 cycling, 6.2 $\mathrm{MPa}$ for 50 cycling and 6.4 MPa for 100 cycling, respectively. In compr essive strength tests, for the $20 \%$ CA-PA/EVM aggregate replacement, the compressive strength is 12.2 $\mathrm{MPa}$ for 0 cycling, $13.5 \mathrm{MPa}$ for 50 cycling and 13.9 MPa for 100 cycling. The enhancement in mechanical properties can be due to the production of more dicalcium silicate $\left(\mathrm{C}_{2} \mathrm{~S}\right)$ via hydration reaction in cement after thermal cycling. Therefore, environmental temperature variation will not reduce the mechanical strength. On the contrary, temperature variation can promote the production of dicalcium silicate, which caused the mechanical enhancement.

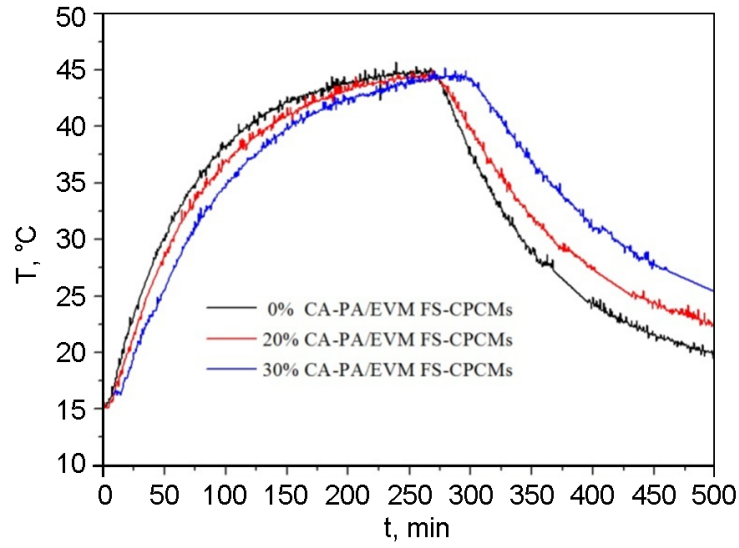

Fig. 10. Temperature evolution curves of the miniaturized test room made of the prepared mortar mixes with different volume fractions of CA-PA/EVM FS-CPCMs in the heating process and cooling process.

\subsection{Thermal performance of mortar mixes with CA-PA/EVM FS-CPCMs}

To evaluate the thermal performance of mortar mixes with CA-PA/EVM FS-CPCMs, heat transfer experiments were performed by investigating the effect of inner temperature of the miniaturized test room made of the prepared mortar mixes in cooling process and heating process. The temperature curves are presented in Fig. 10. As shown in Fig. 10 compared with the test room made of mortar mixes without FS-CPCMs, the temperature of the room made of mortar mixes with FS-CPCMs changed more slowly during the heating process. For example, the time taken to reach the maximum temperature $\left(45^{\circ} \mathrm{C}\right)$ is $239 \mathrm{~min}$ for $0 \%$ FS-CPCMs replacement, $242 \mathrm{~min}$ for $20 \%$ FS-CPCMs replacement and $291 \mathrm{~min}$ for $30 \%$ FS-CPCMs replacement, respectively. Moreover, after the heating process, the inner temperature of the mortar mixes with FS-CPCMs dropped more slowly compared with that of the mortar mixes without FS-CPCMs. The 
time that the temperature fell from $45{ }^{\circ} \mathrm{C}$ to $25^{\circ} \mathrm{C}$ was $150 \mathrm{~min}$ for $0 \% \mathrm{FS}-\mathrm{CPCM}$ s replacement, $190 \mathrm{~min}$ for $20 \%$ FS-CPCMs replacement and $219 \mathrm{~min}$ for $30 \%$ FS-CPCMs replacement, respectively. The result indicates that the mortar mixes with CA-PA/EVM FS-CPCMs can be utilized as preferred phase change material for the purposes of building thermal regulation and energy saving.

\section{Conclusion}

This paper reported the fabrication and characterization of CA-PA/EVM FS-CPCMs for the purposes of thermal regulation and energy saving. CA-PA binary mixture acted as PCM and EVM was utilized as supporting material. The CA-PA/EVM FS-CPCMs were firstly prepared by adsorption method. The EVM had the optimal adsorption rate when the mass ratio of CA-PA to EVM was 45:55. FT-IR results indicate that the FS-CPCMs possess good stability without chemical reaction between binary mixture and EVM. After 50 thermal cycling, the enthalpy of CA-PA/EVM composite changed slightly, which was acceptable in melting process. However, the enthalpy obviously changed in the freezing process. Further studies should be implemented to enhance the thermal stability. Moreover, the mortar mixes with aggregate replacement of CA-PA/EVM FS-CPCMs were prepared, and the mechanical experiments indicate that the flexural and compressive strength reduced more significantly when the volume of CA-PA/EVM FS-CPCMs aggregate replacement was greater than $30 \%$. The evaluation of the thermal performance indicates that the mortar mixes with CA-PA/EVM FS-CPCMs are preferential potential materials for thermal regulation and energy saving in buildings.

\section{References}

1. L. Yang, H.Y. Yan, J.C. Lam, , Appl Energ, 115, 164, 2014.

2. D. Zhou, C.Y. Zhao, Y. Tian, Appl Energ, 92, 593, 2012.

3. R. Parameshwaran, S. Kalaiselvam, S. Harikrishnan, A. Elayaperumal, Renew.Sust.Energ. Rev., 16, 2394, 2012.

4. U. Stritih and V. Butala, Int J.Refrig., 33, 1676, 2010.

5. G. Zhou, Y. Zhang, X. Wang, K. Lin, W. Xiao, Sol Energ, 81, 1351, 2007.

6. S.A. Memon, Renew.Sust.Energ.Rev., 31, 870, 2014.

7. A. Karaipekli, A. Sarə, Sol. Energ. Mater. Sol.C., 149, 19, 2016.

8. Y. Hong and G. Xin-shi, Sol. Energ. Mater. Sol. C, 64, 37, 2000 .

9. D.A. Kontogeorgos, G.K. Semitelos, I.D. Mandilaras, M.A. Founti, Fire Safety J, 81, 8, 2016.

10. B. Mohammadi, F.S. Najafi, H. Ranjbar, J. Mohammadi, M. Zakaryazadeh, Energ Build, 118, . 99, 2016.

11. A. Karaipekli, A. Sarə, J .Ind. Eng. Chem., 16, 767, 2010.

12. X. Li, H. Wei, X. Lin, X. Xie, Sol. Energ. Mater. Sol.C., 155, 9, 2016.

13. H. Wei, X. Xie, X. Li, X. Lin, Appl Energ, 178, 616, 2016.

14. X. Xiao, P. Zhang, M. Li, Energ Conv. Manag, 105, 272, 2015.

15. Y.J. Lv, W.B. Zhou, W.Z. Jin, Energ. Build., 111, 242,2016

16. J. Zhang, X. Guan, X. Song, H. Hou, Z. Yang, and J. Zhu, Energ. Build., 92, 155, 2015.

17. C. Jiao, B. Ji, D. Fang, Mat. Lett., 67, 352, 2012.

18. L. Jiesheng, Y. Yuanyuan, H. Xiang, Energ. Build.,110, 108, 2016.

19. A. Sarэ, A. Karaipekli, Mater. Chem, Phys., 109, 459, 2008.

20. D. Zhang, S. Tian, D. Xiao, Sol Energ, 81, 653, 2007.

21. X. Fang, Z. Zhang, Z. Chen, Energ Conv.Manag., 49, 718, 2008.

22. Y. Wang, H. Zheng, H.X. Feng, D.Y. Zhang, Energ.Build., 47, 467, 2012.

23. Y. El Mouzdahir, A. Elmchaouri, R. Mahboub, A. Gil, S.A. Korili, Powd. Techn., 189, 2, 2009. 